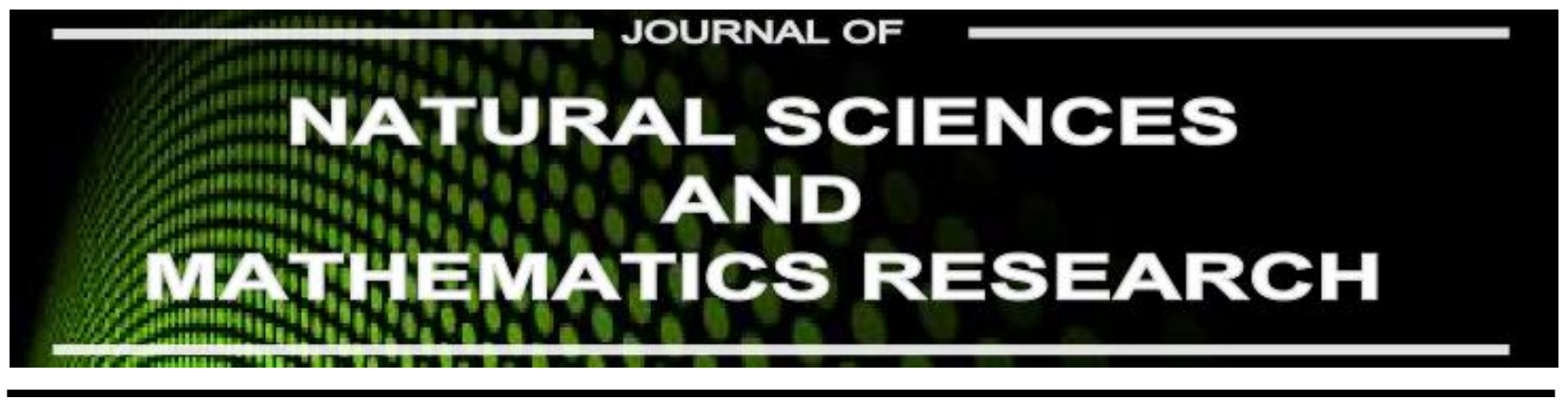

Available online at http://journal.walisongo.ac.id/index.php/jnsmr

\title{
The Characteristics of Material DSSC (Dye-Sensitized Solar Cell) Solar Cell from Extraction of Teak Leaves
}

\section{Hamdan Hadi Kusuma}

Department of Physics Education, Universitas Islam Negeri Walisongo, Central Java, Indonesia

\begin{abstract}
s
Corresponding author: coesma@yahoo.com

Recived: 02 April 2016, Revised : 02 May 2016 Accepted: 20 June 2016.

The research of solar cell with using dye from natural materials as a sensitizer in a dye-sensitized solar cell (DSSC) continues to grow. One advantage of the DSSC is does not require a material with high purity so that the production cost is relatively low. This research aims to analyze the characteristics of the absorption band of teak leaf extract. Extraction of teak leaves dissolved in a mixture of ethanol and acetic acid with a variation ratio of 1: $0,1: 1$ and 5.66: 1, resulting in a solution of each color reddish yellow, reddish brown and dark red. Absropsi test results with UV-Vis spectrometer showed that there are peaks in the absorbance in the visible region, ie at wavelengths between $500 \mathrm{~nm}$ to $560 \mathrm{~nm}$. This shows that the dye material of teak leaf extract may work or absorb the green color. While absobption other peaks are also found in pektrum wavelength of $580 \mathrm{~nm}$, $600 \mathrm{~nm}$ and $660 \mathrm{~nm}$, each of which can absorb the green color yellow, orange and red. (C)2016 JNSMR UIN Walisongo. All rights reserved.
\end{abstract}

Key words: Extracts; Teak Leaves; DSSC.

\section{Introduction}

Solar energy is often referred to as solar cell energy, because that solar energy can be converted into electrical energy with the help of solar panels. Solar energy will not run out as long as the sun is still glowing, unlike the energy of fossil materials. One way to convert solar energy into electrical energy is to use solar cells. A solar cell is a device that can convert solar energy into electrical energy using photovoltaic effects. The photovoltaic effect was first discovered by Becquerel in 1839 to detect a photo tension when the sun rays the electrodes in an electrolyte solution [1].

In this decade, technological developments are very fast, the dominance of the use of silicon materials for solar cell panels began to be replaced with a new generation, namely by using Dye-Sensitized Solar Cell (DSSC). The advantage of DSSC is that it does not require high purity material, so the production cost is relatively low [2]. In 
addition, DSSC materials are capable of absorbing light and electrically discharging. Light absorption is performed by dye and electrical charge separation by nanocrystalline inorganic semiconductors that have large band gaps. One of the most commonly used semiconductor materials is $\mathrm{TiO}_{2} . \mathrm{TiO}_{2}$ material is relatively cheap, widely found, inert and also non-toxic [3].

The use of dye as a sensitizer in DSSC for solar cells can be produced from synthetic or natural dye. Natural dye is obtained by extracting from parts of plants such as leaves, flowers or fruit [4]. Different types of plant extracts have been used as photosensitizers in dye sensitized solar cell systems. Natural DyeSensitizers already used in DSSC systems include black berries [5], Rosella flower [6], pomegranate fruit [7], mangosteen fruit [8,9], bunis fruit [10], Red cabbage [11] and dragon fruit [12]. These natural dyes have been shown to provide a photovoltaic effect even if the resulting efficiency is still much smaller than the synthetic type of dye. Nevertheless, organic dyestuffs are highly competitive to serve as dye materials for solar cells because of the low cost of prooduction and the manufacturing process does not require high technology, but also the isolation process is also easier. [11]. Teak leaves have the potential to be used as dye material for solar cells, because teak leaf extracts can be produced by dyes that are in the ultra violet spectrum and are able to absorb a wide spectrum of light..

In this paper we report on teak leaf extract as dye for sensitized materials in solar cells with different concentrations of ethanol and acetic acid and characterization analysis of absorption spectra in the dye solution.

\section{Experiments Procedure}

Sample solution of teak leaf extract as dye for the sensitized material in solar cells has been successfully fabrication. The dye samples from the teak leaf extract were prepared by variation of the ratio of solvent mixture between ethanol and acetic acid with each comparison 1 : 0 (sample-A) ; 1: 1 (sample B); and $5.65: 1$ (sample $C$ ). The dye solution was characterized by absorption test using a UV Visible Single Visible UV (UV-Vis) OPTIZEN 2120 UV (UV-Vis) spectrometer at a wavelength of $450 \mathrm{~nm}$ to $700 \mathrm{~nm}$ to determine absorbance of visible wavelength, so dye solution functioned as dye material for DSSC material.

\section{Result and Discussion}

The synthesis of natural dyes from teak leaf extract as dye material in DSSC, generally has a reddish-brown specification. The results of teak leaf extract on sample A, sample B and sample $\mathrm{C}$ solution are yellow-reddish, reddish and dark red, respectively. The color of the solution produced from centers by using some aqueous solvents combined with ethanol and acetic acid with the variation of the solvent ratio is to determine the nature of the natural dye produced, especially in the behavior of light absorption.

The absorption peak of sample $A$ as shown in Table 1. According to Table 1, the absorbance result of the teak leaf extract density solution is peaked at $470 \mathrm{~nm}$ wavelength, this means that the teak leaf dye solution can work on a halogen light spectrum that absorbs the turquoise color. Other absorption peaks also found in teak leaf dye solution (sample A) are present on the 500 $\mathrm{nm}$ and $530 \mathrm{~nm}$ wavelength spectrum This absorption peak will absorb the green color spectrum (500 nm - $560 \mathrm{~nm})$ and this corresponds to the resulting extract color which is reddish. While the absorption peak at $610 \mathrm{~nm}$ wavelength indicates that the dye solution of teak leaves can also work or absorb the red color spectrum. So, teak leaf extracts that use only ethanol and aquades solvents can work by absorbing the light spectrum of turquoise, green and red. The graph of the relationship between the wavelength and the absorption peak of the dye solution in sample A can be seen in Figure 1. 
Tabel 1. The peak absorption of teak leaf extract with ethanol and acetic acid ratio of 1:0 (sample A)

\begin{tabular}{cc}
\hline Wavelength (nm) & $\begin{array}{c}\text { Intensity of } \\
\text { absorption (a.u) }\end{array}$ \\
\hline 470 & 1.600 \\
500 & 1,163 \\
530 & 0.867 \\
610 & 0.380 \\
\hline
\end{tabular}

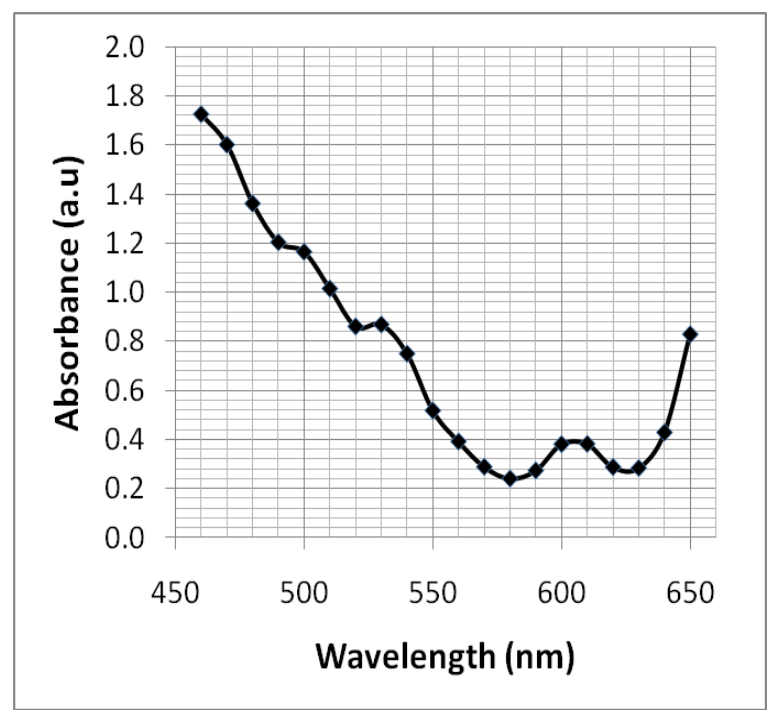

Figure 1. The graph of wavelength relation with absorbance of teak leaf extract with ethanol and acetic acid ratio of 1: 0 (sample A).

The absorption peak of sample $\mathrm{B}$ as shown in Table 2, there is an absorbance peak at $500 \mathrm{~nm}, 520 \mathrm{~nm}$ and $560 \mathrm{~nm}$ wavelengths, this means that dye extract of teak leaf can work on a green color spectrum $(500 \mathrm{~nm}$ $560 \mathrm{~nm}$ ) and this corresponds to the color of the extract produced, which is dark red. Another absorption peak is also found at 600 $\mathrm{nm}$ wavelength, indicating that the teak dye solution can also work or absorb the orange spectrum. While the other absorbance peak is on the $660 \mathrm{~nm}$ wavelength spectrum with the highest absorbance compared to other peaks, so the dye solution of teak leaves will also work by absorbing the red color. Teak leaf extract using aquades solvent, ethanol and acetic acid with a ratio of 5.66: 1 can work by absorbing the spectrum of green, orange and red. The graph of the relationship between the wavelength and the absorption value of the dye solution in sample B can be seen in Figure 2.

Tabel 2 The peak absorption of teak leaf extract with ethanol and acetic acid ratio of 1:1 (sample B)

\begin{tabular}{cc}
\hline Wavelength (nm) & $\begin{array}{c}\text { Intensity of } \\
\text { absorption (a.u) }\end{array}$ \\
\hline 500 & 2.337 \\
520 & 1.963 \\
560 & 1,086 \\
580 & 0.790 \\
\hline
\end{tabular}

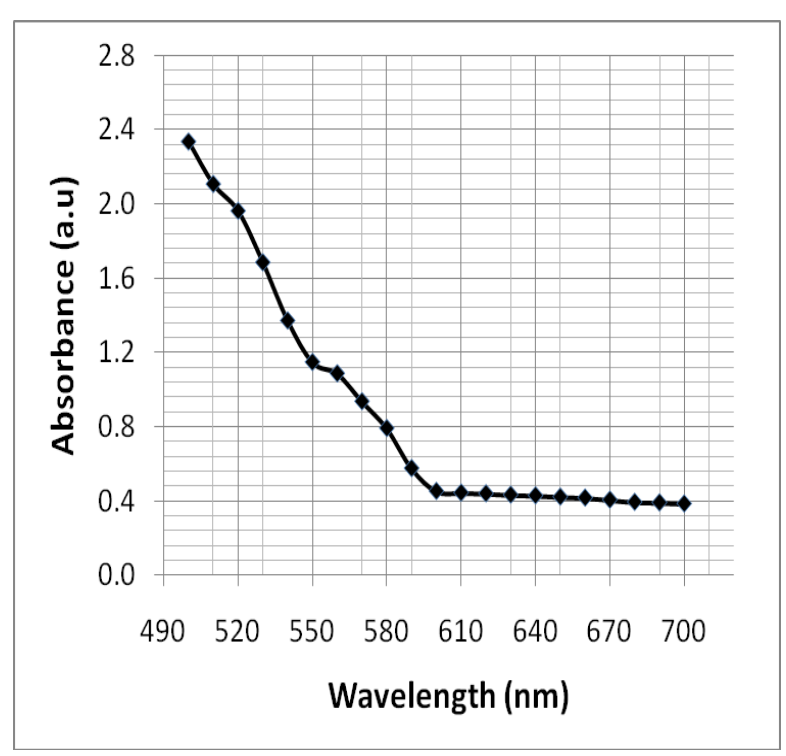

Figure 2. The graph of wavelength relation with absorbance of teak leaf extract with ethanol and acetic acid ratio of $1: 1$ (sampel B)

The absorption peak of sample $\mathrm{C}$ as shown in Tabel 3, there is an absorbance peak at $500 \mathrm{~nm}$, and $530 \mathrm{~nm}$ wavelength, meaning that dye extracts of teak leaf extract can work on a green color spectrum (500 nm - $560 \mathrm{~nm}$ ). This is in accordance with the color of teak leaf extract produced is reddish color. While the absorption peak at $580 \mathrm{~nm}$ wavelength indicates that the dye solution of teak leaf extract can work or absorb the yellowish green light. So teak leaf extract using aquades, ethanol and acetic acid 1: 1 ratio can work by absorbing green and yellowish green. The graph of the relationship between the wavelength and the absorption value of the 
dye solution in sample $\mathrm{C}$ can be seen in Figure 3.

Tabel 3. The peak absorption of teak leaf extract with ethanol and acetic acid ratio 5.66:1 (sample C)

\begin{tabular}{cc}
\hline Wavelength (nm) & $\begin{array}{c}\text { Intensity of } \\
\text { absorption (a.u) }\end{array}$ \\
\hline 500 & 0.494 \\
530 & 0.364 \\
600 & 0.191 \\
660 & 0.717 \\
\hline
\end{tabular}

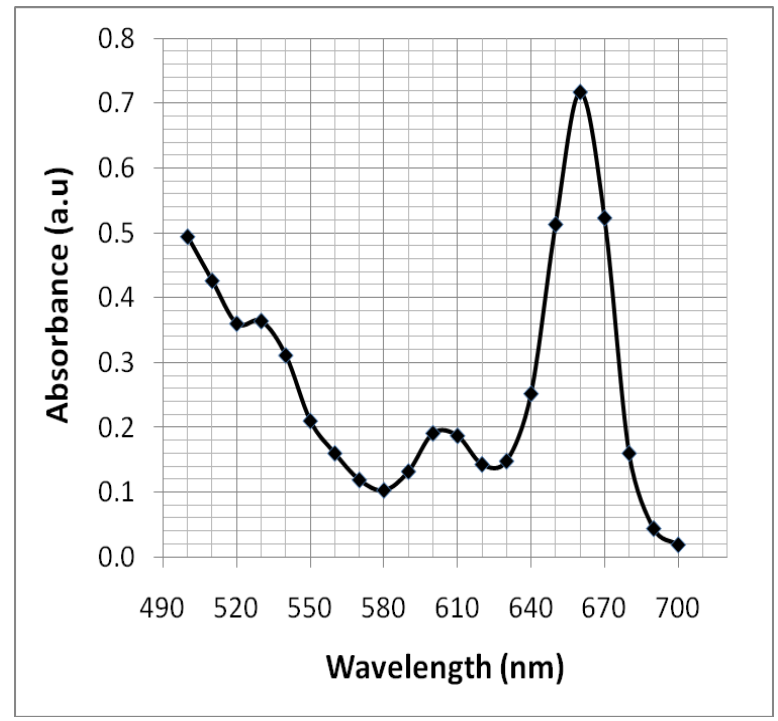

Figure 3. The graph of wavelength relation with absorbance of teak leaf extract with ethanol and acetic acid ratio of $5,66: 1$ (sample $\mathrm{C}$ )

The extract of dye from teak leaves by varying the solvent generally indicates that the material can be used as dye material in DSSC solar cells. The results of the absorption using the UV-Vis spectrometer showed that the resulting spectrum of peaks in the area of the visible range of light. In general, the three samples show the absorbance peaks in the spectrum range with wavelengths ranging from $500 \mathrm{~nm}$ to $560 \mathrm{~nm}$. This indicates that the dye material from teak leaf extract can work or absorb light green color. While, the other absorption peaks are also found on the wavelength $580 \mathrm{~nm}, 600 \mathrm{~nm}$ and $660 \mathrm{~nm}$ wavelength, each of which can absorb the yellowish green, orange and red color.

The results of this absorbance test can also be used to indicate the presence of anthocyanin. Based on absorbance data shows that there are absorbance peaks at visible wavelength range of light, it can be indicated that the teak leaf extract specimen contains anthocyanin. This anthocyanin is very sensitive to visible light, so the dye solution is a good candidate for dye materials in the DSSC of solar cell.

\section{Conclusion}

The synthesis of natural dyes from teak leaf extract as dye material in DSSC generally has a reddish-brown color with visible light absorption peaks in the wavelength range from $500 \mathrm{~nm}$ to $660 \mathrm{~nm}$. These absorption peaks indicate that the natural dye of the teak leaf extract contains anthocyanin and is a good candidate for dye in the DSSC of solar cell.

\section{Acknowledgment}

The author wish to thank to LP2M, Universitas Islam Negeri Walisongo Semarang for the financial support.

\section{References}

[1] R. Sastrawan, Photovoltaic Modules of Dye Solar Cell, Desrtasi Unviresity of Freiburg. 2006.

[2] W.D. Septiana, Fajarasandi, dan M. Aditia, Pembuatan Prototype Solar cell Murah dengan Bahan Organik-Inorganik. Laporan Penelitian Bidang Energi, Institur Teknologi Bandung, Bandung. 2007.

[3] M. Gratzel, Dye Sensitized Solar Cells, Journal of Photochemstry and Photobiology. Vol 4, pp. 145-153, 2003.

[4] A. Maddu, M. Zuhri, dan Irmansyah, Penggunan Ekstrak Antosianin Kol Merah sebagai Fotosentizer pada Sel Surya $\mathrm{TiO}_{2}$ Nanokristal Tersentiasi Dye, departemen 
Fisika FMIPA, Institut Pertanian Bogor.Bogor. 2007.

[5] S. Ali, Biomimicry in Solar Energy Convertion with Natural Dye Sensitized Nanocrytstalline Phitivotaic ells, Department of hemistry and Biochemistry Obelin ollege, Ohio, 4-6. 2007.

[6] K.V. Wongcharee, S. Meeyo. And Chavadej, Dye Sensitized Solar Cell Using Natural Dye Exctracted From Rosella and Bleu Pea Flowers, Deparment of hemical Enginering Mahanakom University of Technology. 2007.

[7] P.M. Sirimanne, M.K.I. Senevirathna, E.V.A. Premal, P.K.D.D.P. Pitigala, V. Sivakumar, and K. Tennakone, Utilization of Natural Pigment Extracted from Pormegranate Fruits as Sentizer in Solid State Cells, Journal Photochemistry and Photobiolgy, Vol. 177, pp. 324-327, 2006.

[8] J. Suryadi, Pembuatan dan Penentuan Nilai effisiensi Sel Surya berperwarna Tersentisitasi dengan senyawa Antosianin dari Buah Manggis, Sebagai Pewarna Pensensitisasi. Jurusan Kimia, Universitas Diponegoro, Semarang. 2009.
[9] W.A. Qosim, Kulit Buah Manggis Sebagai Antioksidan, Anekaplansantia Cybermedia clips. 2007.

[10] D.L. Pangestuti, Pembuatan Dye sensitized Solar ell dengan Sensitizer Antosianin dari buah Buni, Jurusan Kimia, Universitas Diponegoro, Semarang. 2009.

[11] L. Anggraini, Pembuatan Dye Sensitized Solar ell dengan Memanfaatkan Sensitizer Ekstrak Kol Merah, Jurusan Kimia Univeritas Diponegoro, Semarang. 2009.

[12] S.M.R. Nageak dan D. Varisi Temperature dan Waktu Tahan Kalsinasi tehadap ujuk kerja Semikonduktor $\mathrm{TiO}_{2}$ sebagi Dye Sensitized Solar Cell dengan Dye Ekstrak Buah Naga Merah. Jurnal Teknik ITS, Vol. 1, 2012. 